\title{
Unusual feline Dirofilaria immitis infection: a case report
}

\author{
Infecção incomum por Dirofilaria immitis em felino: relato de caso \\ Bruno Alberigi1* (1); Alexandre Calmon de Oliveira²; Grazielle Silva Rodrigues Vieira²; \\ Priscila do Amaral Fernandes ${ }^{3}$; Norma Labarthe ${ }^{4}$; Flavya Mendes-de-Almeida ${ }^{5}$ \\ 'Departamento de Medicina e Cirurgia Veterinária, Instituto de Veterinária, Universidade Federal Rural do Rio de Janeiro - UFRRJ, \\ Seropédica, RJ, Brasil \\ 2 Médico veterinário autônomo, Rio de Janeiro, RJ, Brasil \\ ${ }^{3}$ Laboratório Laborlife Análises Clínicas, Rio de Janeiro, RJ, Brasil \\ ${ }^{4}$ Programa de Pós-graduação em Bioética, Ética Aplicada e Saúde Coletiva, Escola Nacional de Saúde Pública, \\ Fundação Oswaldo Cruz - FIOCRUZ, Rio de Janeiro, RJ, Brasil \\ ${ }^{5}$ Departamento de Patologia e Clínica Veterinária, Faculdade de Veterinária, Universidade Federal Fluminense - UFF, Niterói, RJ, Brasil
}

How to cite: Alberigi B, Oliveira AC, Vieira GSR, Fernandes PA, Labarthe N, Mendes-de-Almeida F. Unusual feline Dirofilaria immitis infection: a case report. Braz J Vet Parasito/ 2020; 29(3): e008420. https://doi.org/10.1590/S1984-29612020061

\begin{abstract}
Cats are less susceptible to Dirofilaria immitis infection than dogs. Although rare, the feline disease can be fatal even with low parasitic loads. The infection is often asymptomatic or has non-specific symptoms that are mainly associated with the death of immature worms. Microfilaremia is rare and transient. Normally, microfilaremia, when present, lasts for not more than 33 days. This study describes a feline case presenting with non-specific clinical signs and prolonged microfilaremia. Case: a random bred cat infected by feline leukemia virus (FeLV) that was found to be microfilaremic by chance. The infection was detected by the presence of microfilariae in a blood smear and was confirmed by antigen test (SNAP Feline Triple Test, Idexx®) and echocardiogram.
\end{abstract}

Keywords: Feline heartworm, microfilaremia, FeLV, diagnosis.

\section{Resumo}

Gatos são menos susceptíveis à infecção por Dirofilaria immitis do que cães. Apesar de rara, a doença nos gatos pode ser fatal mesmo com baixas cargas parasitárias. Muitas vezes, a doença é assintomática ou apresenta sintomas inespecíficos, principalmente associados com a morte de formas parasitárias imaturas. Microfilaremia é rara e transitória. Normalmente, quando ocorre microfilaremia, ela permanece por, no máximo, 33 dias. Este estudo descreve o caso de um felino que apresentava sinais inespecíficos e microfilaremia prolongada: um gato sem raça definida, portador de infecção pelo vírus da leucemia felina (FeLV) que foi diagnosticado como microfilaremico ao acaso. A infecção foi detectada pela presença de microfilárias em esfregaço sanguíneo e, posteriormente, confirmada pelo teste de antígenos (SNAP Feline Triple Test, Idexx®) e por ecocardiograma.

Palavras-chave: Dirofilariose felina, microfilaremia, FeLV, diagnóstico.

\section{Introduction}

Cats are less susceptible to $D$. immitis infection than dogs (Blagburn et al., 2011). The prevalence of infection in cats corresponds to $5 \%$ to $15 \%$ of the canine infection rate in a given area. Feline heartworm infection, although rare, is life threatening in many cases. Even the presence of a few worms can be fatal (Jones et al., 2020). The infection is mostly asymptomatic or presents as non-specific findings upon physical examination. Clinical signs are usually presented when the juvenile worms arrive in the pulmonary arteries or when they die (McCall et al., 2008). The common clinical signs are vomiting, anorexia, lethargy, and weight loss. Cough and dyspnea are observed in rare, severe cases of heartworm-associated respiratory disease (HARD), which occurs when the immature worms die and can be misdiagnosed as asthma (Blagburn \& Dillon, 2007; Garrity et al., 2019). It has also been observed that death of adult worms in cats could be fatal (Jones et al., 2020). 
Diagnosis of feline $D$. immitis infection is challenging. It involves microfilariae test, serological test, thorax radiography, and echocardiogram that can be used in combination. Microfilaremia is a rare evidence, the presence of circulating microfilaria is observed only from 195 days post infection, up until 228 days at the most (33 days) (Jones et al., 2020). Therefore, the tests for microfilariae have very low sensitivity. Although, feline serological tests are $100 \%$ specific, they are considered to have good sensitivity, only if the cat harbors at least one mature female worm. Chest radiographs may show characteristic evidences of the infection, contributing to increased suspicion of heartworm disease in cats (Dillon, 1984; Venco et al., 2015). Echocardiogram is another diagnostic tool, which is used to visualize typical parallel lines of hyperechoic structures, approximately $1.3 \mathrm{~mm}$ in size in the right chambers of the heart or in pulmonary arteries (Venco et al., 2015). Therefore, the most effective methods for diagnosis are chest radiographs, echocardiogram, and serological tests. However, serological test kits are unavailable in Brazil.

The aim of this case report is to stress the need to increase feline heartworm disease awareness among small animal practitioners and encourage diagnosis of feline $D$. immitis in cats that inhabit canine heartworm endemic areas, despite non-specific clinical presentation.

\section{Case Description}

On a home call at Ilha do Governador, Rio de Janeiro, RJ, the attending veterinarian examined a 6-year-old outdoor/indoor, FeLV positive, random bred, neutered male cat. This cat lived with another adult cat that showed no clinical signs and was not examined at owners discretion. The cat presented with one week history of illness, sporadic vomiting and hind limb lameness. The clinical examination revealed the presence of high fever $\left(40^{\circ} \mathrm{C}\right)$, lameness, heavy flea infestation, hyporexia, panting, swollen lymph nodes, and lethargy. The cat received symptomatic treatment with antipyretics, analgesics and antiemetics. Selamectin was prescribed monthly to control flea infestation. Given the history and clinical examination, it was initially suspected to be an infection by Mycoplasma spp. Therefore, a blood sample was collected for examination and oral doxycycline (6 mg/kg BID) was prescribed for 2 weeks.

Blood work revealed the presence of discrete anisocytosis, polychromasia, leukopenia, and lymphopenia. Blood urea nitrogen (BUN) and creatinine were within the normal range. Alanine transaminase (ALT) was increased by 2.5-fold. Microfilariae were observed in the blood smear and PCR assay did not detect DNA of any Mycoplasma spp.. According to the owner, the cat's health was regained in a week.

On the $34^{\text {th }}$ day after the first physical examination, the veterinarian followed up with the cat and collected a blood sample to test for D. immitis antigens using SNAP Feline Triple Test (imported by Idexx Brazil for research) and recheck for microfilariae. The cat was active and showed no clinical signs. He tested positive for $D$. immitis and FeLV antigens and negative for feline immunodeficiency virus (FIV) antibodies. Microfilariae was detected via Knott's modified test and buffy coat examination.

On the $60^{\text {th }}$ day after the first physical examination, the cat was presented at the clinic. At the time, he was active and uncooperative, presenting harsh expiratory lung sounds with no other clinically detectable signs of disease. The owner claimed that the cat seemed healthy at home. A blood sample was taken for laboratory examination and echocardiogram was also performed. Thoracic radiography was postponed at the owner's discretion.

The echocardiogram showed presence of $1.3 \mathrm{~mm}$ parallel linear hyperechoic structures in the main pulmonary artery (Figure 1). No signs of pulmonary hypertension were detected. However, color Doppler showed the presence of slight tricuspid regurgitation and (Figure 2) spectral Doppler showed asymmetric systolic and pulmonic flow with normal velocity (Figure 3). No other changes, such as changes in cardiac chamber size or function were observed. Laboratory work showed that the cat was still leukopenic and microfilaremic.

No further examinations were possible due to the SARS-CoV-2 pandemic that imposed social isolation.

\section{Discussion}

The presence of microfilaremia for at least 60 days suggests that the host-parasite relationship was somehow impaired. As the prepatent period ended before the first blood sample was obtained and microfilaremia still persisted after the last examination, the time period of microfilaremia in this case was longer than that observed in experimental infections and natural infections (Jones et al., 2020). The time of infection development is unknown because the cat always lived at the same place. However, it can be inferred that the non-specific clinical signs presented by the cat on the first visit could be result of $D$. immitis arrival in the lungs. 


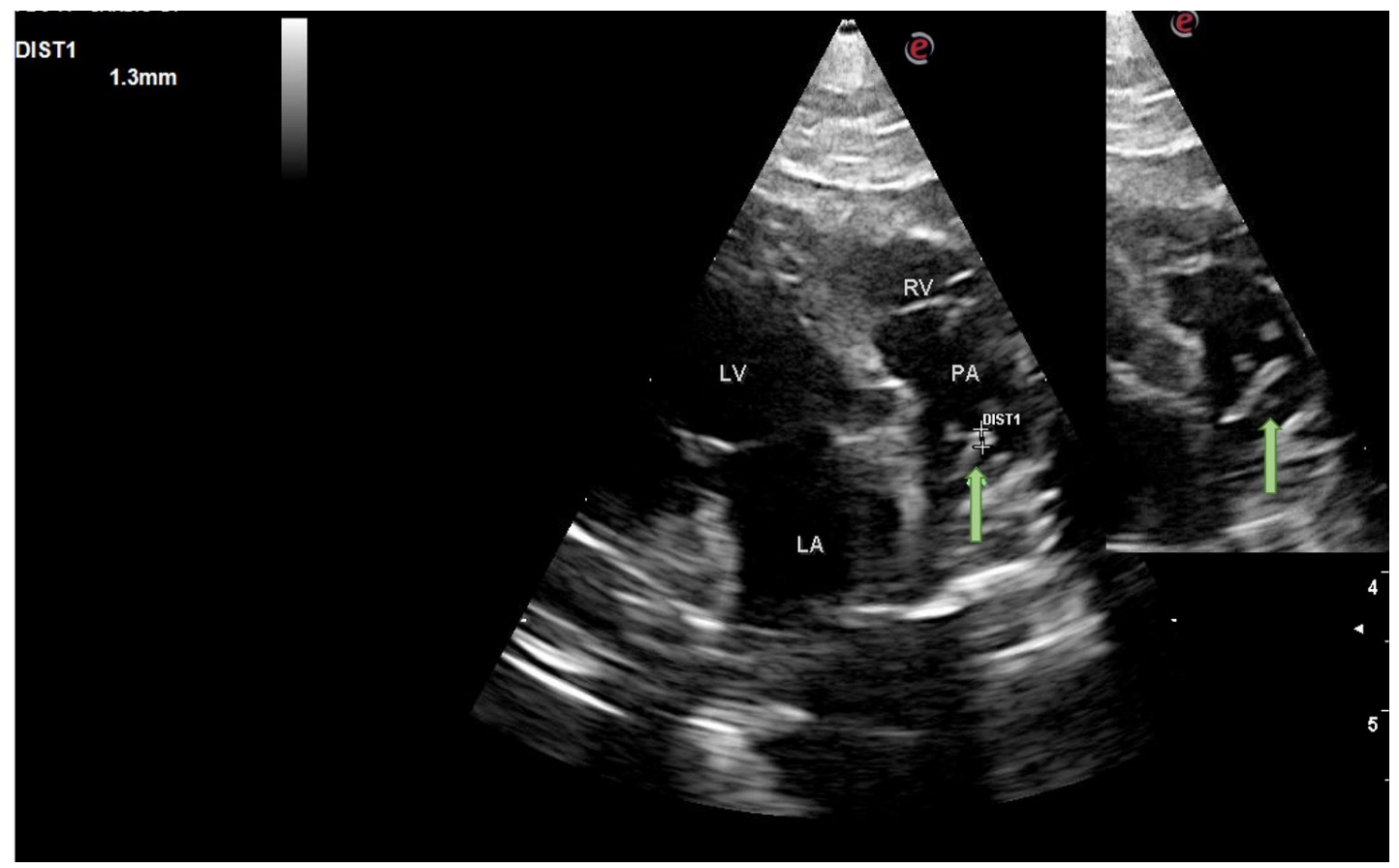

Figure 1. Echocardiographic image with slight modification in the left ventricular outflow view allowing the visualization of hyperechoic linear structures in the main pulmonary artery, associated with $D$. immitis infection (arrow). LV= left ventricle; $\mathrm{LA}=$ Left atrium; RV= Right ventricle; PA= Pulmonary artery, DIST=Distance.

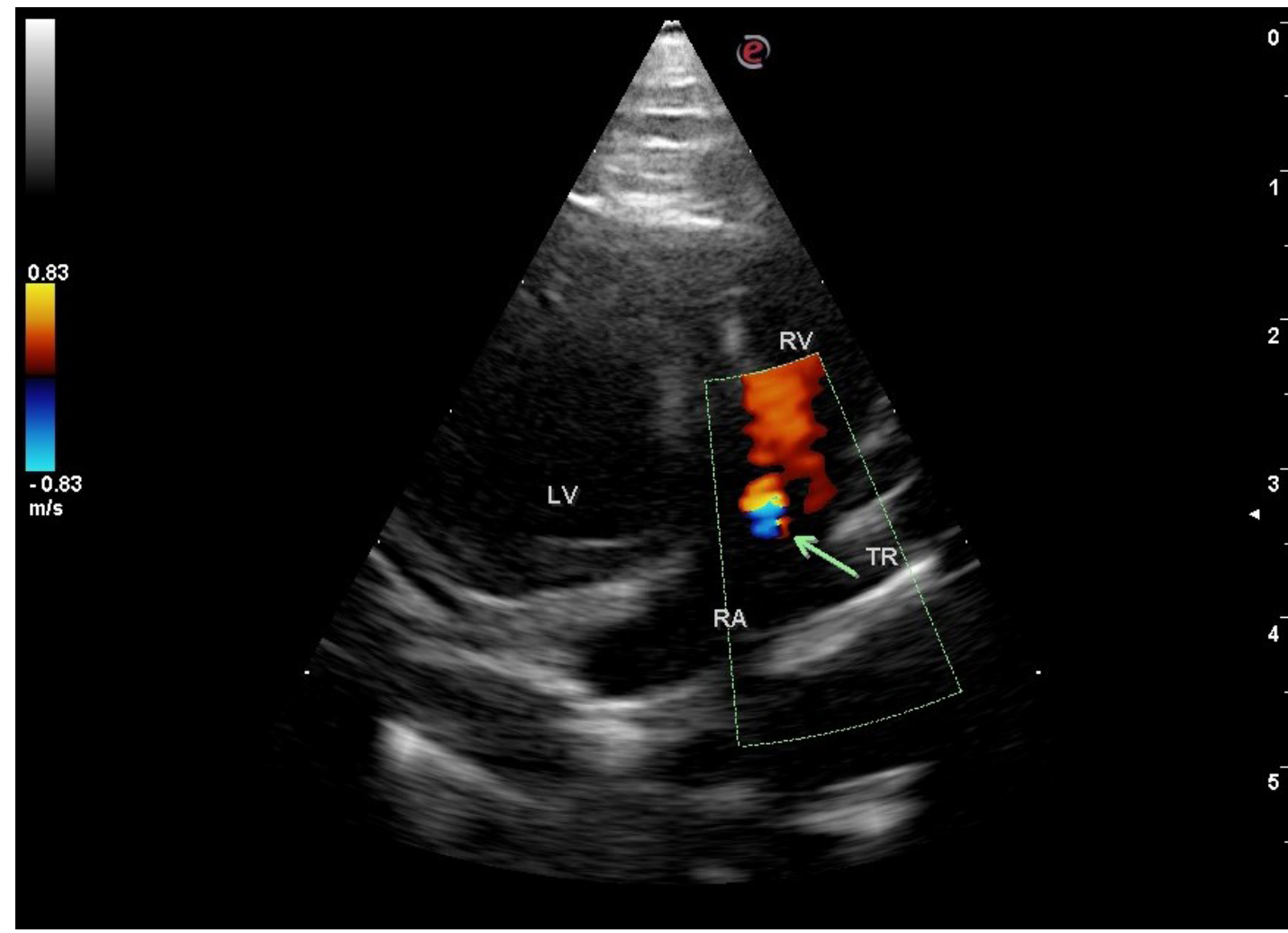

Figure 2. Echocardiographic color Doppler image in the left parasternal modified apical four-chamber view showing tricuspid regurgitation (arrow). LV= left ventricle; $R A=$ right atrium, $R V=$ right ventricle; $T R=$ tricuspid regurgitation.

The inflammatory reaction that is expected to occur when worms arrive in the lungs may have been attenuated by the clinical signs that kept the cat inactive and by the down-regulation live worms impose to the pulmonary intravascular macrophages (Dillon et al., 2008). On the $60^{\text {th }}$ day, the cat did not present any signs of clinical 


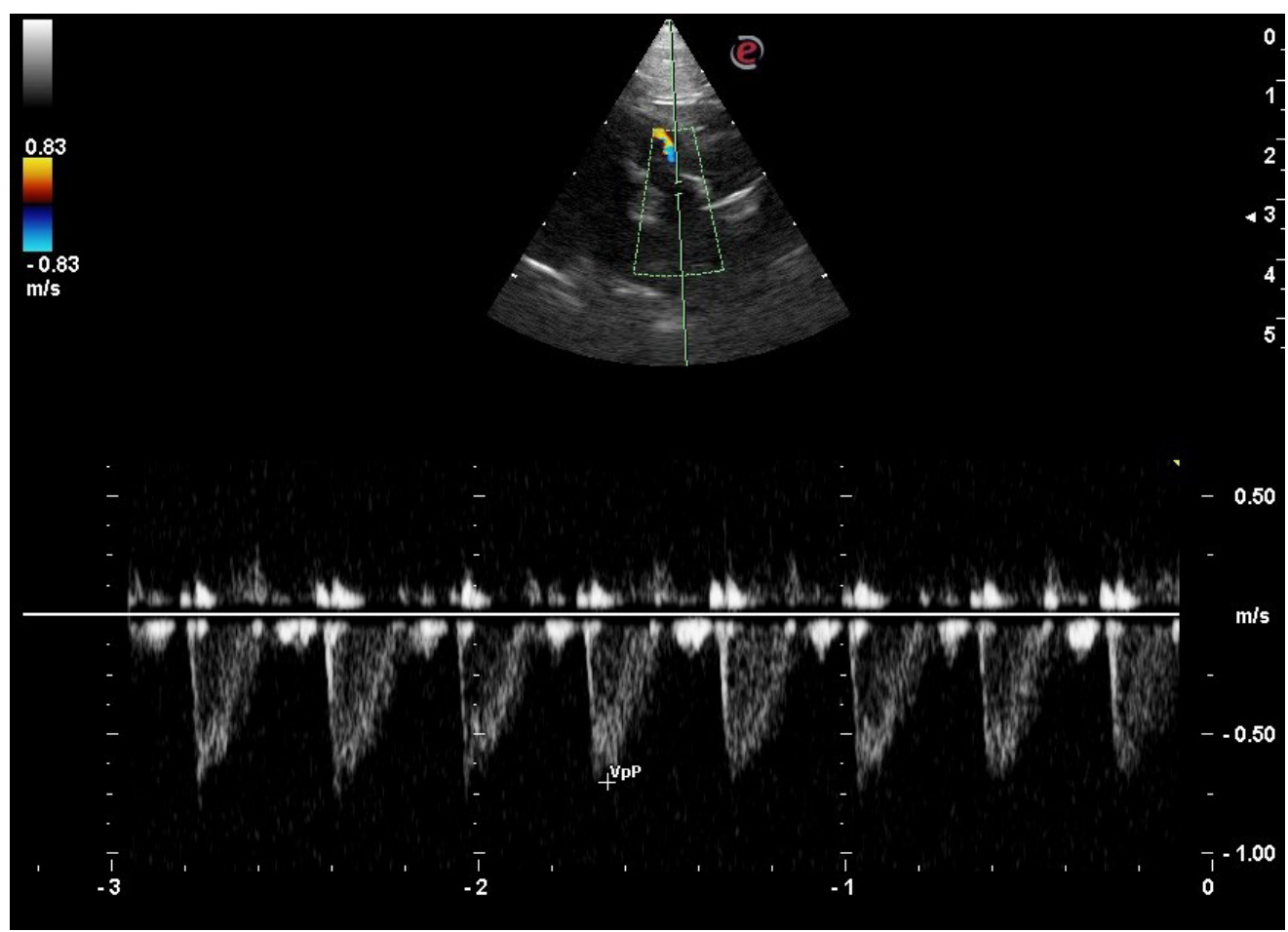

Figure 3. Echocardiographic spectral Doppler image of pulmonary artery showing asymmetric systolic and pulmonic flow with normal velocity $0.70 \mathrm{~m} / \mathrm{s}$.

manifestations of acute respiratory disease, although harsh expiratory lung sounds were present indicating pulmonary inflammation. This reaction, even if minimal, was enough to cause constriction of small airways in lungs. The presence of tricuspid regurgitation and asymmetric systolic pulmonic flow observed can be interpreted as increased right cardiac chambers pressure (Johnson, 2016; Chetboul, 2016) although, in order to confirm it elevated tricuspid regurgitation velocity ( $>2.5 \mathrm{~m} / \mathrm{s})$, right chambers enlargement and flattening of interventricular septum should have been detected by echocardiography (Côté et al., 2011).

FeLV is another factor contributing to immunosuppression, inhibiting the cats ability to combat microfilariae, and impairing severe pulmonary inflammation. The association of heartworm with FeLV infection is rare and seldom documented. As live adult heartworms suppress feline immune function (Venco et al., 2015) and FeLV impairs Th1 response (Cockerell et al., 1976; Sykes \& Hartmann, 2014), it is possible that the lack of severe clinical signs and the persistence of microfilaremia may have been favored by the co-infection.

\section{Conclusions}

In the present case study, the absence of severe clinical signs of heartworm infection could be associated with co-infection of two immune system down-regulating organisms, FeLV and live $D$. immitis.

\section{References}

Blagburn BL, Dillon AR, Arther RG, Butler JM, Newton JC. Comparative efficacy of four commercially available heartworm preventive products against the MP3 laboratory strain of Dirofilaria immitis. Vet Parasitol 2011; 176(2-3): 189-194. http://dx.doi. org/10.1016/j.vetpar.2010.12.049. PMid:21295409.

Blagburn BL, Dillon AR. Feline heartworm disease: solving the puzzle. Vet Med 2007; 102(Suppl): 7-14.

Chetboul V. Pulmonary arterial hypertension. In: Madron E, Chetboul V, Bussadori C, editors. Clinical echocardiography of the dog and cat. Missouri: Elsevier; 2016. p. 229-240.

Cockerell GL, Hoover EA, Krakowka S, Olsen RG, Yohn DS. Lymphocyte mitogen reactivity and enumeration of circulating B-and T-cells during feline leukemia virus infection in the cat. J Natl Cancer Inst 1976; 57(5): 1095-1099. http://dx.doi.org/10.1093/ jnci/57.5.1095. PMid:187790. 
Côté E, MacDonald KA, Meurs KM, Sleeper M. Pulmonary Thromboembolism and Hypertension. In: Côté E, MacDonald KA, Meurs KM, Sleeper M, editors. Feline cardiology. West Sussex: John Wiley \& Sons; 2011. p. 383-391. http://dx.doi.org/10.1002/9781118785782.

Dillon AR, Warner AE, Brawner W, Hudson J, Tillson M. Activity of pulmonary intravascular macrophages in cats and dogs with and without adult Dirofilaria immitis. Vet Parasitol 2008; 158(3): 171-176. http://dx.doi.org/10.1016/j.vetpar.2008.09.004. PMid:18977090.

Dillon R. Feline dirofilariasis. Vet Clin North Am Small Anim Pract 1984; 14(6): 1185-1199. http://dx.doi.org/10.1016/S01955616(84)50153-3. PMid:6393552.

Garrity S, Lee-Fowler T, Reinero C. Feline asthma and heartworm disease: clinical features, diagnostics and therapeutics. J Feline Med Surg 2019; 21(9): 825-834. http://dx.doi.org/10.1177/1098612X18823348. PMid:31446863.

Johnson LR. Cor pulmonale and pulmonary thromboembolism. In: Tilley LP, Smith FWK, Oyama MA, Sleeper MM, editors. Manual of canine and feline cardiology. 5th ed. Missouri: Elsevier; 2016. p.181-187.

Jones S, Graham W, Von Simson C, Stannard R, Carithers D, Payne P, et al. Current feline guidelines for the prevention, diagnosis, and management of heartworm (Dirofilaria immitis) infection in cats [online]. Wilmington: American Heartworm Society; 2020 [cited 2020 Mar 31]. Available from: https://d3ft8sckhnqim2.cloudfront.net/images/pdf/2020_AHS_Feline_Guidelines.pdf?1580934824

McCall JW, Genchi C, Kramer LH, Guerrero J, Venco L. Heartworm disease in animals and humans. In: Rollinson D, Hay SI. Advances in parasitology. New York: Academic Press; 2008. p. 193-285.

Sykes JE, Hartmann K. Feline Leukemia Virus Infection. In: Sykes JE. Canine and feline infectious diseases. 1st ed. St. Louis: Elsevier; 2014. p. 224-238. http://dx.doi.org/10.1016/B978-1-4377-0795-3.00022-3.

Venco L, Marchesotti F, Manzocchi S. Feline heartworm disease: a ‘Rubik's-cube-like' diagnostic and therapeutic challenge. J Vet Cardiol 2015; 17(Suppl 1): S190-S201. http://dx.doi.org/10.1016/j.jvc.2015.08.004. PMid:26776577. 